\title{
CORRESPONDENCE
}

Correspondents are asked to be brief

Constitution of G.M.C.

T. F. Buckley, F.R.C.S.

Tuberculin Anergy

Lieutenant Colonel A. M. Munster, F.

Agreement between Clinical and Radio-

logical Diagnosis

Experimental Infection of Man with Pig Whipworm

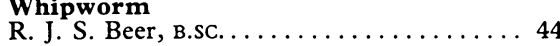

Recurrent Erythema Nodosum of Pregnancy

E. G. Daw, M.R.C.o.G.

Pyrexia and Dialysis

Elizabeth A. Bowie, M.B.

Salicylates and Papillary Necrosis

R. S. Nanra, M.R.A.C.P., and P. Kincaid Smith, F.R.C.P...

Phenacetin Nephropathy

H. E. de Wardener, F.R.C.P., and K. G. Koutsaimanis,

Diabetic Ketoacidosis and Influenza R. Haijar, M.D. ............... 46

Exposure Treatment for Phobias

M. Z. Hussain, D.P.M., and G. Nolan ..... 46
Alopecia and Levodopa

A. J. Marshall, M.R.C.P., and M. J. Williams, M.R.C.P. ................. 47

Amino-acids in Fetal Fluids

G. Morrow, M.D. . ............ 47

Laparoscopy Hazard

R. Herrera-Llerandi, M.D......... 47

General Practitioners and Medical Television

J. H. Walker, M.D., and others.........47

Heel Cushion on the Operating Table

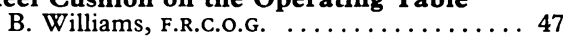

Uneasy Relations

R. S. Atkinson, F.F.A.R.C.S

A Psychiatrist in Space?

L. C. Kreeger, D.P.M. . .

D. H. Wilson, F. Services .....

Treating the Mentally Subnormal

R. Payne, D.P.M. . . . . . . . . . . 48

Treatment of Pediculosis

G. W. Roberts, D.P.H. ...........49

Hypertonic Solutions to Induce Abortion
I. L. Craft, F.R.C.S., and B. D. Musa, M.B...
Migraine Variants

B. de F. Olivarius, M.D. . ...........49

Cytomegalovirus Meningo-encephalitis

T. G. M. Perham, M.B., and others ..... 50

Gynaecology in General Practice

W. Hunter, F.R.C.o.G. . . . . . . . . . . 50

Clinical Trials of Prostaglandins

D. Mansel-Jones, M.B. ........... 50

Encouraging Recruits to Medicine

J. G. TAYLOR .............. 51

Payment for Designated Areas

F. E. Webb, M.B., and others .......... 51

The Ward Sister

G. H. Jennings, F.R.C.P. $\ldots \ldots \ldots \ldots \ldots 51$

Seebohm Sequel

D. T. Maclay, M.D. ............ 51

A Case of Confidence

P. H. Woodcock, M.B.; W. Joan Ferraby, M.B. 52

James Hinton, 1822-1875

Esther Blanc, M.A. . . . . . . . . . . . . . 52

\section{Constitution of G.M.C.}

SIR,-The working party on the new role of the G.M.C. (Supplement, 6 March, p. 55) has examined most of the problems involved.

Reference is made to the place of the doctors and medical schools of the Republic of Ireland in the restructured G.M.C. A body of opinion in Britain feels that the southern sented in London as a similar body exists in Dublin; also, that the possible advent of the Common Market will solve any problems that remain in respect of southern Ireland. In its appendices dealing with possible methods of proportional representation on the restructured G.M.C. the working party suggests continuing representation of doctors from the Irish Republic.

I wish to endorse this suggestion. I know from discussions with several fellowcountrymen that there is a considerable body of Irish opinion that regards the medical links with Britain as being of the utmost importance. By this means it is in Ireland. I am, etc., Irish doctors should no longer be repre-

assured that the standards of medical education remain at a comparable level and that the standards in Ireland will continue to improve with those in the United Kingdom. Free movement of doctors will remain uninhibited and this will benefit both countries. The transatlantic influence on medical training in Ireland will not be unduly increased. This is not to decry transatlantic standards of medical practice and patient care but rather to emphasize that the British type of training is better suited to conditions

The links between medical educators and practitioners in Britain and the Irish Republic should be fostered rather than severed. It is to be hoped that the present happy state of affairs will long remain thus.

T. F. BUCKLEY Walton Hospital,
Liverpool

Tuberculin Anergy

SIR,-Your leading article of 5 December, p. 573, makes no reference to extensive burns, in which tuberculin anergy is known to occur. ${ }^{1}$ The mechanism of this anergy remains obscure despite much experimental work on cellular immunity in burned patients and animals. Peritoneal macrophage migration-inhibition remains normal, ${ }^{2}$ and tritiated thymidine incorporation by burn lymphocytes is actually increased ${ }^{34}$ The rejection of small allografts is delayed, ${ }^{56}$ but the rejection of large allografts is normal. It seems that the central immune response following thermal injury is probably unaffected, and the fault lies somewhere in the afferent arc. Further investigations of whole cellular immune process. - I am, etc.,

ANDREW M. MUNSTER

U.S. Army Institute of Surgical Research, Brooke Army Medical Centre,
Fort Sam Houston, Texas, U.S. A.

1 Rapaport, F. T., and Converse, J. M., in Research in Burns, ed. A. B. Wallace, and A. M. 1966

2 Rapaport, F. T., Sampath. A., Kano, K. McCluskey, R. T., and Milgram, F. Fournal of E"perimental Medicine. 1969, 130. 1411.

3 Daniels, J. C., et al., Surgery, Gynecology and Obstetrics, 1970, 130,783.

Euranius, K., and Mortensen, R., International
Archives of Applied Immunology, 1971, in press.
Regional Neurosurgical Centre, 5 Rapaport, F. T., Converse, J. M., Horn, L., Annals of Surgery, 1964, 159, 390

Chambler, K., and Batchelor, J. R., Lancet, 1969,

$1,16$.

\section{Agreement between Clinical and Radiological Diagnosis}

SIR,-I acknowledge the need for, and indeed, strongly support well conceived and carried out studies to assess the accuracy, effectiveness, usefulness, etc., of radiology as a specialty many such studies have been published. I was, however, greatly disappointed when I read a recent article by Dr. G. R. Sutherland on "Agreement between Clinical and Radiological Diagnosis" (24 October, p. 212). The author alleges to measure the "diagnostic contribution of radiology", and although the data are interesting I believe they are, for the most part, unrelated to the title of the paper, irrelevant to the conclusions drawn, and the conclusions are misleading.

Most of the data in this paper appear to relate to detection of abnormalities by radiography rather than to agreement with real clinical diagnoses as the title suggests. The two are quite different. How can a radiologist conditions leading to tuberculin anergy may reading skull films agree with a clinical

throw some light on our knowledge of the diagnosis of headache, vertigo, or syncope, tension on an intravenous pyelogram? If nothing is detected on the I.V.P. or the skull films, and in fact, it is later proved that there is no renal cause for the hypertension or organic cause for the headache, this should score as agreement with the true lesion and not as lack of agreement, as was done in this paper. Even in areas reported as having good clinical-radiological correlation-such as abdominal $x$-rays ordered from the obstetrics department-the reader is not certain of the value or meaning of the data. What were the clinical diagnoses: ?fetal maturity, pelvi- 